\title{
An empirical study on measurement of efficiency of digital transformation by using data envel- opment analysis
}

\author{
Mehmet Nuri İnel ${ }^{a^{*}}$
}

\begin{tabular}{|c|c|}
\hline CH R O N I C L E & A B S T RACT \\
\hline $\begin{array}{l}\text { Article history: } \\
\text { Received: October 23, } 2018 \\
\text { Received in revised format: No- } \\
\text { vember } 24,2018 \\
\text { Accepted: January 14, } 2019 \\
\text { Available online: } \\
\text { January } 14,2019 \\
\text { Keywords: } \\
\text { Digital transformation } \\
\text { Efficiency } \\
\text { Data envelopment analysis }\end{array}$ & $\begin{array}{l}\text { Nowadays digitalization is an important topic for businesses and government agencies. There are } \\
\text { important reports publishing about digitalization or digital transformation. This study aims to } \\
\text { measure the relative efficiency of digital transformation among EU Countries based on data envel- } \\
\text { opment analysis (DEA). The necessary data are extracted from Digital Transformation Scoreboard } \\
2018 \text { published by European Commission. DEA is one of popular methods for measuring the rel- } \\
\text { ative efficiency of similar units. This study empirically proposes an alternative ranking for coun- } \\
\text { tries with respect to digital transformation efficiency by using "enablers and output" approach of } \\
\text { Digital Transformation Scoreboard. Digital Infrastructure, Investment and Access to Finance, Sup- } \\
\text { ply and Demand of Digital Skills, E-Leadership and Entrepreneurial Culture are considered as } \\
\text { input while ICT start-ups and Digital Transformation are considered as the output of DEA model. } \\
\text { The results indicate that while some countries like Denmark, Italy and United Kingdom are con- } \\
\text { sidered relatively efficient, Netherland and Germany are not very efficient according to our results. }\end{array}$ \\
\hline
\end{tabular}

\section{Introduction}

Digital transformation is an important topic for businesses and countries in this era. Technical improvements and applications enable us to improve digital transformation on both businesses and countries, rapidly. This study investigates the efficiency of digital transformation in this study. The aim of this study is to measure the relative efficiency of digital transformation using data envelopment analysis (DEA). There are many reports about digital transformation and one of them is Digital Transformation Scoreboard 2018 (Digital Transformation Scoreboard, 2018) published annually by European Commission. The study data and the application framework are taken from this report. The concept of DEA with different methods and approaches, is used in many studies and practices as one of efficiency measurement analysis. In this study, DEA is implemented to measure of the relative efficiency of digital transformation. The study has three main sections. The first and the second sections include literature of DEA and digitalization. The third section includes application of measurement efficiency and finally section four provides the conclusion of the paper.

\footnotetext{
* Corresponding author

E-mail address: mninel@marmara.edu.tr (M. N. İnel) 
The literature review of digital transformation and DEA methods are described in this section. Since the digital transformation is an important topic, we need to measure the effectiveness of the method.

There are different studies in the literature that measure the relative efficiency of countries instead of efficiency of digital transformation. Kaynar et al. (2005) measured the relative efficiency of the telecommunication sector located in OECD region using DEA method. Aksu and Gencer (2018) also measured the relative environmental performance in OECD countries using DEA. Raab and Kotamraju (2006) measured the efficiency of high tech economies using DEA in United States. Chodakowska and Nazarko (2017) applied environmental efficiency analysis and evaluated the productivity of European Countries using DEA method.

Ceccobelli et al. (2012) used DEA method to measure the impact of information and communication technology (ICT) on labor productivity on 14 OECD countries. Angeriz et al. (2006) used DEA to assess indices of total factor productivity, technological change and efficiency in Europe countries. Filippetti and Peyrache (2015) also used DEA to assess Labor Productivity and Technology Gap in Europe countries. Mitrovic (2015) used DEA based model to analyze dynamics and the level of the digital information in Western Balkan Countries. Kumar and Russell (2002) used DEA to measure the efficiency technological catch-up in 57 countries. Chetty et al. (2018) measured digital literacy to create some useful index. DEA method was also used for ranking in the literature (Mehrabian et al., 1999)

It is shown that there were significant number of studies, which implement DEA to measure efficiency of countries as macro dimension in the literature. In this paper, we use DEA method to measure the relative efficiency of digital transformation in EU countries.

\section{Data Envelopment Analysis}

DEA was born first through a study by Farrel (1957). DEA has been one of the most popular methods for measuring the relative efficiency of decision making units developed first by Charnes et al. (1978), which was based on constant return to scale (CCR). According to Melao (2005), DEA basically measures the relative efficiency of multiple outputs and inputs of decision making units. It evaluates decision making units according to efficient frontiers, which gives scores for every units (Shim \& Kantor, 1999). There are different assumptions about DEA. The extension of CCR was developed by Banker et al. (1984). They proposed variable returns to scale assumption called BCC model (Banker et al., 1984; Cooper et al., 2007). Both method have output and input oriented approaches. As a mathematical programming approach, objective function for particular decision making units evaluate generally and symbolically (Cooper et al., 2011),

$$
\max h_{o}(u, v)=\frac{\sum_{r} u_{r} y_{r o}}{\sum_{i} v_{i} x_{i o}}
$$

Definition, formulas and assumption details of CCR and BCC were explained by Cooper et al (2011). There are different DEA based approaches in the literature. Because of using CCR and BCC; input and output oriented assumptions in application of study, these assumptions are shortly explained in this section.

\section{Digital Transformation}

Digital transformation is one of favorite topics nowadays. This topic influences on economic environment as well as businesses and countries. There are many approaches to define digital transformation in the literature. According to Reddy and Reinartz (2012) digital transformation has two definitions and one of these is to use internet and computer to create effective economic value with respect to traditional sense. The other definition wholly states changes of new technology in operation, interaction, configuration and creation of wealth with respect to broader sense. Schallmo et al. (2017) investigated definition of digital transformation and proposed definition of digital transformation for their 
digital transformation of business models research. According to Schallmo et al. (2017) digital transformation includes networking business, customers, segments and requires data analysis to reach information used to evaluate options that increases business performance.

Berman (2012) suggested to reshape costumer value and transform operations based on digital technologies to reach grater customer collaboration and interaction for the success of digital transformation. Digitalization of countries can be measured with six key attributes: ubiquity, affordability, reliability, speed, usability and skill (El-Darwiche et al. 2012)

In the literature, Schwarzmüller et al. (2018) investigated how the digital transformation affects the organizations. Majchrzak et al. (2016) performed an investigation on designing for digital transformation. Balyer and Öz (2018) investigated digital transformation on education according to academicians' perspective. Bouwman et al. (2018) investigated generally impacts of digitalization for SMEs. Motta (2016) also investigated impacts of digitalization about socio economic development. Li et al. (2018) investigated capability of SME's for digital transformation. Loonam et al. (2018) investigated some case studies about digital transformation. Digital transformation affects world economy, helps to emergence of concepts such as digital economy (Unctad, 2017).

Westerman et al. (2011) investigated a research on executives about digital transformation. According to executives, digital transformation has three main areas of customer experience, business models and operational process. Every area has elements that have shown in Table 1.

Table 1

A Part of Building Blocks of the Digital Transformation Source: (Westerman et al. 2011)

\begin{tabular}{ccc} 
Customer Experience & Operational Process & Business Models \\
Customer Understanding & Process Digitalization & Digitally Modified Business \\
Top Line Growth & Worker Enablement & New Digital Business \\
Customer Touch Points & Performance Management & Digital Globalization \\
\hline
\end{tabular}

\subsection{Digitalization Index}

There are different reports about digitalization or digital transformation. They assess countries with respect to traits of digitalization and one of them published annually by European Commission is digital transformation scoreboard. It especially investigates Europe countries. As the name suggests, the report includes a scoreboard. The scoreboard is a part of digital transformation monitor. The scoreboard contains indicators in two different areas. These are enablers and outputs. Enablers have five categories and outputs have two categories. These indicators assess the development of digital transformation in 28 EU Countries. The seven-category is defined and shown in Fig. 1 (Digital Transformation Scoreboard 2018).

\begin{tabular}{|c|c|c|c|c|}
\hline $\begin{array}{c}\text { Digital } \\
\text { Infrastructures }\end{array}$ & $\begin{array}{c}\text { Investment and } \\
\text { Access to Finance }\end{array}$ & $\begin{array}{c}\text { Supply and } \\
\text { Demand of Digital } \\
\text { Skills }\end{array}$ & E- Leadership & $\begin{array}{c}\text { Entrepreneurial } \\
\text { Culture }\end{array}$ \\
\hline $\begin{array}{c}\text { Enterprises } \\
\text { possessing and } \\
\text { using digital tools }\end{array}$ & $\begin{array}{c}\text { Investments related } \\
\text { to digitalization } \\
\text { and access to } \\
\text { finance }\end{array}$ & $\begin{array}{c}\text { Widespread digital } \\
\text { skills } \\
\text { Integration of Digital Technology } \\
\text { Companies are increasingly using digital technologies } \\
\text { to obtain digital } \\
\text { skills }\end{array}$ & $\begin{array}{c}\text { People favor } \\
\text { entrepreneurial } \\
\text { behavior }\end{array}$ \\
\hline \multicolumn{4}{|c|}{ ICT Start-ups } \\
\hline \multicolumn{5}{|c|}{ Outputs } \\
\hline
\end{tabular}

Fig. 1. Indicator-Based Monitoring of Digital Transformation Source: Digital Transformation Scoreboard 2018 
Digital transformation scoreboard was built in four main (Indicators, survey, real time data, policy analysis) methodological framework shown in Fig. 2.

\begin{tabular}{|l|l|}
\hline $\begin{array}{l}\text { Indicator } \\
\text { Monitoring digital transformation based on the analysis of national data sourced from national statistics offices and } \\
\text { international organizations } \\
\text { Enablers } \\
\text { Digital Infrastructures }\end{array}$ \\
\begin{tabular}{c|} 
Investment and Access to Finance \\
Supply and Demand of Digital Skills \\
E- Leadership \\
Entrepreneurial Culture
\end{tabular} \\
\begin{tabular}{c|c|} 
Integration of Digital Technology \\
Digital Transformation Enablers' \\
Index (DTEI)
\end{tabular} & Digital Technology Integration Index \\
\hline
\end{tabular}

\begin{tabular}{|l}
$\begin{array}{l}\text { Survey } \\
\text { Gathering information about the uptake of mature and emerging digital technologies by EU companies and its impact on } \\
\text { company's performance }\end{array}$ \\
Nine Technology \\
3D Printing / Big Data and Data Analytics / Mobile Services / Cybersecurity Solutions / Cloud Technologies / Social \\
Media / Internet Of Things / Robotic \& Automated Machinery / Artificial Intelligence \\
Eight Dimension \\
Digital Economy / Digital Skills / Digital Technologies / Digital Transformation / Digital Strategy / Digital Investments / \\
Digital Adoption / Impact
\end{tabular}

Real Time Data

Estimating the interest and acceptance of digital technologies and technological solutions online using a digital intelligence platform

\section{Digital Pulse}

Volume / Engagement / Sentiment

\section{Policy analysis \\ Providing a general overview of digital advancement of COSME countries \\ Four Dimensions}

Digital Transformation Performance / Strengths and Areas for Improvement / EU Comparison/ Good Policy Practices

Fig. 2. Framework of the Digital Transformation Scoreboard 2018

Source: Digital Transformation Scoreboard 2018

In this study, we use the indicators of enablers and output to measure efficiency of digital transformation in EU Countries.

\section{Application}

In this study, the efficiency of digitalization transformation is measured in EU countries by data envelopment analysis. We use indicators of digital transformation scoreboard 2018 to measure effectiveness. EU countries is ranked according to effectiveness scores. In the ranking process, we compare different data envelopment analysis approaches.

\subsection{Methods}

Data envelopment analysis was used to measure the efficiency. CCR method input and output oriented assumptions and BCC method input and output oriented assumptions are applied and the results are compared by using EMS (Efficiency Measurement System: A Data Envelopment Analysis (DEA) Software, Link: http://www.holger-scheel.de/ems/). Digital infrastructure, investments and access to finance, supply and demand of digital skills, e-leadership, entrepreneurial culture, ICT start-ups, digital transformation data of 27 European countries are used in data envelopment analysis. Romania is not analyzed due to lack of data. Data of 27 European countries are obtained from digital transformation scoreboard 2018 report for year 2017. 


\subsection{Data Envelopment Analysis Application}

In this study, data are analyzed to measure the efficiency of digital transformation by EMS program created according to the model of this study that is shown in Fig. 3. Inputs and outputs are determined according to digital transformation scoreboard approach, because the scoreboard proposed a model for measuring digital transformation (Digital Transformation Scoreboard 2018). Each European country was designed as a decision-making unit for data envelopment analysis.

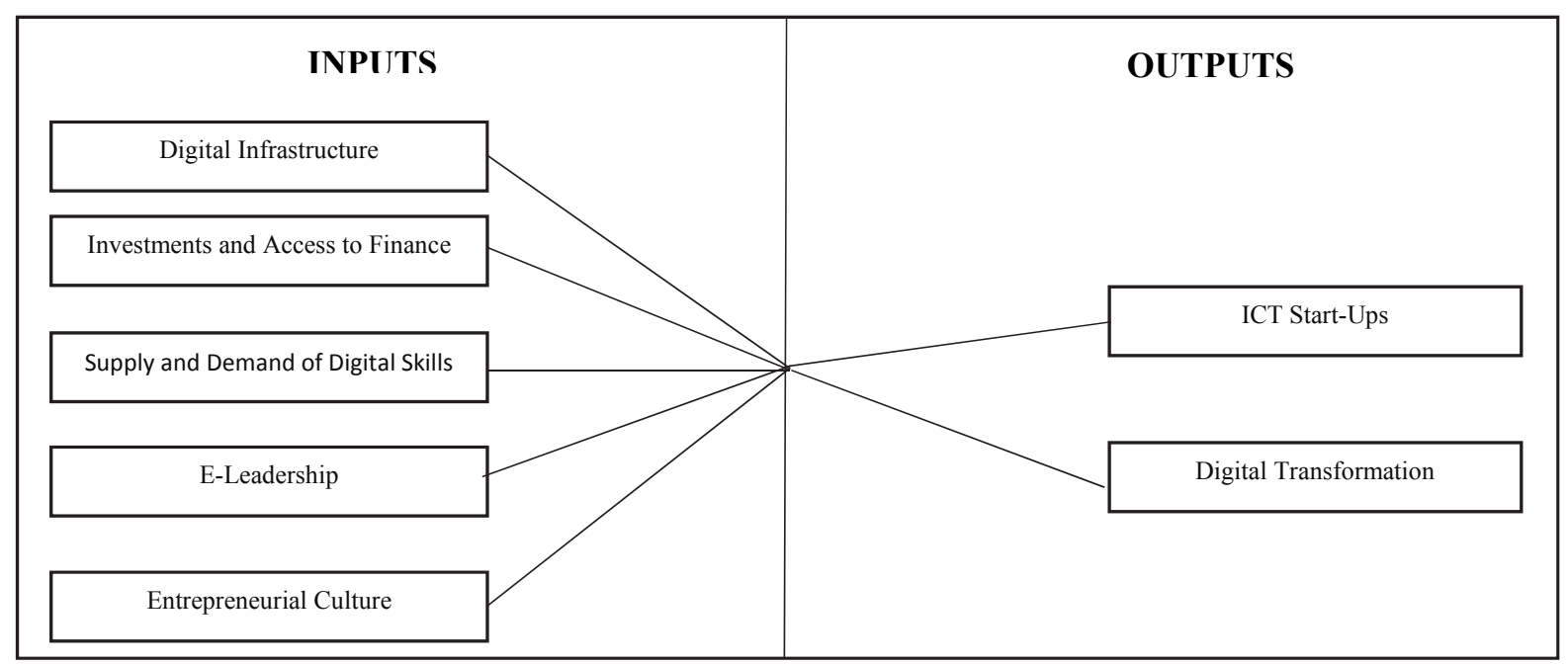

Fig. 3. The Model of Study

Data consist of inputs and outputs of model for 27 European Countries are collected and organized to calculate in EMS program shown in Table 2. We have also calculated super efficiency for both CCR and BSS methods. Thus, eight different calculations have been applied by EMS program. These are input, output, super efficiency input, super efficiency output approaches for CCR method; input, output, super efficiency input, super efficiency output approaches for BCC method.

Table 2

Index Scores of Digital Transformation Framework

\begin{tabular}{|c|c|c|c|c|c|c|c|}
\hline Countries & $\begin{array}{l}\text { Digital Infra- } \\
\text { structure }\end{array}$ & $\begin{array}{c}\text { Investments } \\
\text { And Access To } \\
\text { Finance }\end{array}$ & $\begin{array}{l}\text { Supply And De- } \\
\text { mand Of Digital } \\
\text { Skills }\end{array}$ & E-Leadership & $\begin{array}{c}\text { Entrepreneurial } \\
\text { Culture }\end{array}$ & $\begin{array}{c}\text { ICT } \\
\text { Start-Ups }\end{array}$ & $\begin{array}{c}\text { Digital Transfor- } \\
\text { mation }\end{array}$ \\
\hline Finland & 76 & 80 & 83 & 97 & 51 & 60 & 37 \\
\hline Belgium & 76 & 77 & 65 & 84 & 77 & 24 & 52 \\
\hline Sweden & 70 & 76 & 86 & 76 & 75 & 76 & 42 \\
\hline Luxembourg & 80 & 74 & 65 & 86 & 60 & 65 & 44 \\
\hline Netherlands & 85 & 71 & 89 & 65 & 100 & 32 & 40 \\
\hline Austria & 59 & 69 & 55 & 76 & 33 & 35 & 39 \\
\hline Germany & 57 & 68 & 53 & 51 & 72 & 22 & 35 \\
\hline France & 52 & 68 & 58 & 60 & 77 & 34 & 56 \\
\hline UK & 46 & 68 & 66 & 70 & 58 & 71 & 54 \\
\hline Czech Republic & 42 & 67 & 34 & 47 & 71 & 41 & 41 \\
\hline Greece & 23 & 55 & 24 & 19 & 58 & 27 & 43 \\
\hline Malta & 67 & 53 & 55 & 57 & 71 & 75 & 30 \\
\hline Hungary & 14 & 51 & 38 & 35 & 70 & 45 & 24 \\
\hline Estonia & 35 & 51 & 47 & 54 & 78 & 68 & 32 \\
\hline Denmark & 78 & 48 & 84 & 78 & 46 & 71 & 62 \\
\hline Italy & 45 & 47 & 27 & 33 & 62 & 29 & 56 \\
\hline $\mathrm{EU}$ & 48 & 46 & 45 & 55 & 68 & 43 & 37 \\
\hline Poland & 16 & 45 & 20 & 36 & 60 & 48 & 48 \\
\hline Portugal & 66 & 40 & 34 & 38 & 96 & 70 & 22 \\
\hline Spain & 67 & 39 & 55 & 72 & 77 & 33 & 46 \\
\hline Ireland & 60 & 37 & 94 & 86 & 76 & 35 & 24 \\
\hline Lithuania & 59 & 34 & 21 & 64 & 79 & 79 & 23 \\
\hline Bulgaria & 13 & 34 & 30 & 41 & 78 & 67 & 22 \\
\hline Slovenia & 48 & 19 & 34 & 69 & 79 & 52 & 30 \\
\hline Latvia & 16 & 16 & 18 & 37 & 80 & 54 & 33 \\
\hline Croatia & 24 & 14 & 24 & 54 & 91 & 38 & 35 \\
\hline Cyprus & 52 & 13 & 53 & 67 & 80 & 34 & 34 \\
\hline
\end{tabular}




\subsection{Results and Discussion}

The efficiency scores of DMUs have been analyzed according to CCR method. The results for comparing and efficiency scores are shown in Table 3. The most efficiency countries for digital transformation according to data and the model of study are empirically countries that are highlighted in bold $(100 \%)$ in first and second columns. Especially, it is stated that efficiency scores vary according to inputs or outputs size. For example Bulgaria has the highest input super efficiency score $(152,71 \%)$ but when we look at Table 2, Bulgaria has maintained the lowest input values in some categories. The other countries like Germany (for example) has performed poorly according to efficiency score $(51,16 \%)$ but when we look at Table 2, Germany has maintained some high input values. This efficiency measure empirically proposes that countries can possess higher output. If a country has low efficiency score, it can be stated that higher outputs can be achieved with the same input scores or vice versa. This is also related to the size of the country and the level of digitization. Especially these scores have been calculated with only 5 inputs and 2 output indicators (according to scoreboard) but countries can have very different indicators for the measurement of digital transformation. The efficiency scores of DMU have been analyzed according to BCC method. The results of comparing and efficiency scores are shown in Table 4. The most efficiency countries for digital transformation according to data and the model of study are empirically countries shown in bold color $(100 \%)$ in first and second columns. Scores of some countries are "big" because of higher scores in third and fourth scores columns.

Table 3

Efficiency Scores According to CCR Method

\begin{tabular}{|c|c|c|c|c|}
\hline DMU & $\begin{array}{l}\text { Score Input } \\
\text { Approach }\end{array}$ & $\begin{array}{l}\text { Score Output } \\
\text { Approach }\end{array}$ & $\begin{array}{c}\text { Score Input } \\
\text { Super efficiency } \\
\text { Annroach }\end{array}$ & $\begin{array}{c}\text { Score Output } \\
\text { Super efficiency } \\
\text { Approach }\end{array}$ \\
\hline Denmark & $100,00 \%$ & $100,00 \%$ & $148,53 \%$ & $67,33 \%$ \\
\hline France & $77,92 \%$ & $128,34 \%$ & $77,92 \%$ & $128,34 \%$ \\
\hline Italy & $100,00 \%$ & $100,00 \%$ & $118,42 \%$ & $84,44 \%$ \\
\hline UK & $100,00 \%$ & $100,00 \%$ & $110,25 \%$ & $90,70 \%$ \\
\hline Belgium & $65,59 \%$ & $152,45 \%$ & $65,59 \%$ & $152,45 \%$ \\
\hline Poland & $100,00 \%$ & $100,00 \%$ & $152,66 \%$ & $65,51 \%$ \\
\hline Spain & $80,65 \%$ & $123,99 \%$ & $80,65 \%$ & $123,99 \%$ \\
\hline Luxembourg & $84,92 \%$ & $117,76 \%$ & $84,92 \%$ & $117,76 \%$ \\
\hline Greece & $100,00 \%$ & $100,00 \%$ & $141,67 \%$ & $70,59 \%$ \\
\hline Sweden & $87,71 \%$ & $114,01 \%$ & $87,71 \%$ & $114,01 \%$ \\
\hline Czech Republic & $69,18 \%$ & $144,56 \%$ & $69,18 \%$ & $144,56 \%$ \\
\hline Netherlands & $46,85 \%$ & $213,44 \%$ & $46,85 \%$ & $213,44 \%$ \\
\hline Austria & $91,13 \%$ & $109,73 \%$ & $91,13 \%$ & $109,73 \%$ \\
\hline Finland & $80,56 \%$ & $124,13 \%$ & $80,56 \%$ & $124,13 \%$ \\
\hline Germany & $51,16 \%$ & $195,48 \%$ & $51,16 \%$ & $195,48 \%$ \\
\hline Croatia & $100,00 \%$ & $100,00 \%$ & $115,06 \%$ & $86,91 \%$ \\
\hline Cyprus & $100,00 \%$ & $100,00 \%$ & $107,87 \%$ & $92,70 \%$ \\
\hline Latvia & $100,00 \%$ & $100,00 \%$ & $152,68 \%$ & $65,50 \%$ \\
\hline Estonia & $91,34 \%$ & $109,49 \%$ & $91,34 \%$ & $109,49 \%$ \\
\hline Malta & $100,00 \%$ & $100,00 \%$ & $103,45 \%$ & $96,67 \%$ \\
\hline Slovakia & $100,00 \%$ & $100,00 \%$ & $129,35 \%$ & $77,31 \%$ \\
\hline Slovenia & $90,70 \%$ & $110,26 \%$ & $90,70 \%$ & $110,26 \%$ \\
\hline Ireland & $46,83 \%$ & $213,55 \%$ & $46,83 \%$ & $213,55 \%$ \\
\hline Hungary & $82,92 \%$ & $120,59 \%$ & $82,92 \%$ & $120,59 \%$ \\
\hline Lithuania & $100,00 \%$ & $100,00 \%$ & $129,57 \%$ & $77,18 \%$ \\
\hline Portugal & $100,00 \%$ & $100,00 \%$ & $112,73 \%$ & $88,71 \%$ \\
\hline Bulgaria & $100,00 \%$ & $100,00 \%$ & $152,71 \%$ & $65,49 \%$ \\
\hline
\end{tabular}

Finally, this study has aimed to measure empirically the relative efficiency of digital transformation. When compared methods, CCR method can be more convenient for ranking purposes because of scores according to data. Most countries, has efficiency of $100 \%$ and scores are similar to BCC method. Some countries have extreme scores according to BCC method. In this study, the digital transformation history of the countries was not taken into account and only it was calculated according to 2017 data of countries. Different results will be obtained by taking into account the past investments and different indicators in the digital transformation of the countries. 
Table 4

Efficiency Scores According to BCC Method

\begin{tabular}{|c|c|c|c|c|}
\hline DMU & $\begin{array}{l}\text { Score Input } \\
\text { Approach }\end{array}$ & $\begin{array}{l}\text { Score Output } \\
\text { Approach }\end{array}$ & $\begin{array}{c}\text { Score Input } \\
\text { Super efficiency } \\
\text { Approach }\end{array}$ & $\begin{array}{c}\text { Score Output } \\
\text { Super efficiency } \\
\text { Approach }\end{array}$ \\
\hline Denmark & $100,00 \%$ & $100,00 \%$ & big & big \\
\hline France & $88,46 \%$ & $102,27 \%$ & $88,46 \%$ & $102,27 \%$ \\
\hline Italy & $100,00 \%$ & $100,00 \%$ & $209,52 \%$ & $84,16 \%$ \\
\hline UK & $100,00 \%$ & $100,00 \%$ & $147,39 \%$ & $90,12 \%$ \\
\hline Belgium & $67,32 \%$ & $115,38 \%$ & $67,32 \%$ & $115,38 \%$ \\
\hline Poland & $100,00 \%$ & $100,00 \%$ & $212,05 \%$ & big \\
\hline Spain & $82,78 \%$ & $116,56 \%$ & $82,78 \%$ & $116,56 \%$ \\
\hline Luxembourg & $88,63 \%$ & $113,12 \%$ & $88,63 \%$ & $113,12 \%$ \\
\hline Greece & $100,00 \%$ & $100,00 \%$ & $175,28 \%$ & big \\
\hline Sweden & $100,00 \%$ & $100,00 \%$ & big & $98,94 \%$ \\
\hline Czech Republic & $78,67 \%$ & $125,65 \%$ & $78,67 \%$ & $125,65 \%$ \\
\hline Netherlands & $60,49 \%$ & $150,67 \%$ & $60,49 \%$ & $150,67 \%$ \\
\hline Austria & $100,00 \%$ & $100,00 \%$ & $142,73 \%$ & big \\
\hline Finland & $86,92 \%$ & $120,35 \%$ & $86,92 \%$ & $120,35 \%$ \\
\hline Germany & $75,95 \%$ & $166,23 \%$ & $75,95 \%$ & $166,23 \%$ \\
\hline Croatia & $100,00 \%$ & $100,00 \%$ & $123,66 \%$ & big \\
\hline Cyprus & $100,00 \%$ & $100,00 \%$ & $110,89 \%$ & big \\
\hline Latvia & $100,00 \%$ & $100,00 \%$ & $168,87 \%$ & big \\
\hline Estonia & $91,76 \%$ & $103,45 \%$ & $91,76 \%$ & $103,45 \%$ \\
\hline Malta & $100,00 \%$ & $100,00 \%$ & $106,09 \%$ & $95,79 \%$ \\
\hline Slovakia & $100,00 \%$ & $100,00 \%$ & $163,64 \%$ & big \\
\hline Slovenia & $97,22 \%$ & $109,98 \%$ & $97,22 \%$ & $109,98 \%$ \\
\hline Ireland & $83,77 \%$ & $194,95 \%$ & $83,77 \%$ & $194,95 \%$ \\
\hline Hungary & $100,00 \%$ & $100,00 \%$ & $105,83 \%$ & big \\
\hline Lithuania & $100,00 \%$ & $100,00 \%$ & big & $73,98 \%$ \\
\hline Portugal & $100,00 \%$ & $100,00 \%$ & $123,03 \%$ & $87,92 \%$ \\
\hline Bulgaria & $100,00 \%$ & $100,00 \%$ & $258,79 \%$ & big \\
\hline
\end{tabular}

\section{Conclusion and Recommends}

This study has empirically proposed to measure the relative efficiency of digital transformation using DEA method. It has empirically shown that DEA can be applied to measure the efficiency of digital transformation. Efficiency scores can vary according to data. Denmark, Italy, UK, Poland, Greece, Croatia, Cyprus, Latvia, Malta, Slovakia, Lithuania, Portugal, Bulgaria were detected efficient countries according to both methods according to both BCC and CCR methods. Approximately 50\% of countries analyzed, are efficient in digital transformation according to two methods. We may apply input, output approach of this study for businesses to measure the efficiency of digital transformation. For further research, properties of data envelopment analysis like benchmarking of decision making units or sensitivity analysis can applies. This efficiency measurement method of digital transformation can be applied for businesses or different countries.

\section{References}

Aksu, E.Ö. \& Gencer, C.T. (2018). Veri Zarflama Analizi İle Oecd Ülkelerinin Çevre Performansının İncelenmesi. International Journal of Economic and Administrative Studies, (18. EYİ Özel Sayıs1) 191-205.

Angeriz, A., Mccombie, J. \& Roberts, M. (2006). Productivity, efficiency and technological change in European Union Regional manufacturing: A data envelopment analysis approach. The Manchester School, 74(4), 500-525.

Balyer, A., \& Öz, Ö. (2018) Academicians' views on digital transformation in education. International Online Journal of Education and Teaching, 5(4), 809-830.

Banker, R.D., Charnes, A., \& Cooper, W.W (1984). Some models for estimating technical and scale inefficiencies in data envelopment analysis. Management Science, 30(9), 1078-1092.

Berman, S. J. (2012). Digital transformation: Opportunities to create new business models. Strategy \& Leadership, 40(2), 16-24.

Bouwman, H., Nikou, S., Molina-Castillo, F.J. \& de Reuver, M. (2018). The impact of digitalization on business models. Digital Policy, Regulation and Governance, 20(2), 105-124.

Ceccobelli, M., Gitto, S. \& Mancuso, P. (2012). ICT Capital and labour productivity growth: A non-parametric analysis of 14 OECD countries. Telecommunications Policy, 36, 282-292. 
Charnes, A., Cooper, W.W., \& Rhodes, E. (1978). Measuring the efficiency of decision making units. European Journal of Operational Research, 2, 429-444.

Chodakowska, E., \& Nazarko, J. (2017) Environmental DEA method for assessing productivity of European countries. Technological and Economic Development of Economy, 23(4), 589-607.

Cooper, W.W., Seiford, L. M., \& Tone, K. (2007). Data Envelopment Analysis A Comprehensive Text with Models, Applications, References and DEA-Solver Software. USA: Springer

Cooper, W.W., Seiford, L. M., \& Zhu, J. (2011). Data Envelopment Analysis: History, Models and Interpretations. In: Cooper W.W. , Seiford L. M. \& Zhu J. (Eds.) Handbook on Data Envelopment Analysis. Springer USA, pp. 1-40

Digital Transformation Scoreboard (2018). EU businesses go digital: Opportunities, Outcomes and Uptake, Publications Office of the European Union, 2018

El-Darwiche, B., Singh, M., \& Ganediwalla, S. (2012). Digitalization and prosperity. Strategy Business, 68, 2-10.

Farrell, M. J. (1957). The measurement of productive efficiency. Journal of the Royal Statistical Society, Series A, 120(3) 253-290.

Filippetti, A., \& Peyrache, A. (2015). Labour productivity and technology gap in European regions: A conditional frontier approach. Regional Studies, 49(4), 532-554

Kaynar, O., Zontul, M. \& Bircan, H. (2005) Veri Zarflama Analizi İle Oecd Ülkelerinin Telekomünikasyon Sektörlerinin Etkinliğinin Ölçülmesi. C.Ü. İktisadi ve İdari Bilimler Dergisi, 6(1), 37-57

Chetty, K., Qigui, L., Gcora, N., Josie, J., Wenwei, L., \& Fang, C. (2018). Bridging the digital divide: measuring digital literacy. Economics: The Open-Access, Open-Assessment E-Journal, 12(2018-23), 1-20.

Kumar, S., \& Russell, R. R. (2002). Technological change, technological catch-up, and capital deepening: relative contributions to growth and convergence. American Economic Review, 92(3), 527-548.

Li, L., Su, F., Zhang, W., \& Mao, J. Y. (2018). Digital transformation by SME entrepreneurs: A capability perspective. Information Systems Journal, 28(6), 1129-1157.

Loonam, J., Eaves, S., Kumar, V., \& Parry, G. (2018). Towards digital transformation: Lessons learned from traditional organizations. Strategic Change, 27(2), 101-109.

Majchrzak, A., Markus, M. L., \& Wareham, J. (2016). Designing for digital transformation: Lessons for information systems research from the study of ICT and societal challenges. MIS Quarterly, 40(2), 267-277.

Mehrabian, S., Alirezaee, M. R., \& Jahanshahloo, G. R. (1999). A complete efficiency ranking of decision making units in data envelopment analysis. Computational optimization and applications, 14(2), 261-266.

Melao, N. (2005). Data envelopment analysis revisited: a neophyte's perspective. International Journal of Management and Decision Making, 6(2), 158-179.

Mitrović, Đ. (2015). Broadband adoption, digital divide, and the global economic competitiveness of Western Balkan countries. Economic Annals, 60(207), 95-115.

Motta, G. (2016) The Impact of Digitalization on Socio-economic Development: An Analysis at the European and Italian Levels (Thesis) Politecnico Di Milano School of Industrial and Information Engineering,

Raab, R. A., \& Kotamraju, P. (2006). The efficiency of the high-tech economy: Conventional development indexes versus: A performance index. Journal of Regional Science, 46(3), 545-562.

Reddy, S., \& Reinartz, W. (2017). Digital transformation and value creation: Sea change ahead. Value in the Digital Era, 9(1), 11-17.

Schallmo, D., Williams, C. A., \& Boardman, L. (2017). Digital transformation of business models - Best practice, enablers and roadmap. International Journal of Innovation Management, 21(8), 1-17.

Schwarzmüller, T., Brosi, P., Duman, D. \& Welpe, I.M. (2018). How does the digital transformation affect organizations? Key themes of change in work design and leadership. Management Revue, 29(2), 114-138.

Shim, W., \& Kantor, P.B. (1999). Evaluation of digital libraries: A DEA approach. Proceedings of the ASIS Annual Meeting, 36, 5-15

UNCTAD (2017). Information Economy Report 2017 Digitalization, Trade And Development, United Nations Conference on Trade and Development.

Westerman, G., Calméjane, C., Bonnet, D., Ferraris, P., \& McAfee, A. (2011). Digital Transformation: A roadmap for billion-dollar organizations. MIT Center for Digital Business and Capgemini Consulting, 1-68.

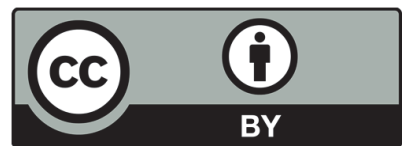

(C) 2019 by the authors; licensee Growing Science, Canada. This is an open access article distributed under the terms and conditions of the Creative Commons Attribution (CC-BY) license (http://creativecommons.org/licenses/by/4.0/). 